Chapman University

Chapman University Digital Commons

English (MA) Theses

Dissertations and Theses

Winter 12-11-2019

\title{
Terrence McNally's Universalizing Model: The Role of Disability in Andre's Mother; Lips Together, Teeth Apart, and Love! Valour! Compassion!
}

Alexa Burnstine

Chapman University, burns141@mail.chapman.edu

Follow this and additional works at: https://digitalcommons.chapman.edu/english_theses

Part of the Dramatic Literature, Criticism and Theory Commons

\section{Recommended Citation}

Burnstine, Alexa. Terrence McNally's Universalizing Model: The Role of Disability in Andre's Mother; Lips Together, Teeth Apart; and Love! Valour! Compassion!. 2019. Chapman University, MA Thesis. Chapman University Digital Commons, https://doi.org/10.36837/chapman.000099

This Thesis is brought to you for free and open access by the Dissertations and Theses at Chapman University Digital Commons. It has been accepted for inclusion in English (MA) Theses by an authorized administrator of Chapman University Digital Commons. For more information, please contact laughtin@chapman.edu. 


\title{
Terrence McNally's Universalizing Model: The Role of \\ Disability in Andre's Mother; Lips Together, Teeth Apart; and Love! Valour! Compassion!
}

\author{
A Thesis by \\ Alexa Paige Burnstine \\ Chapman University \\ Orange, CA \\ Master of Arts in English \\ December 2019 \\ Committee in charge: \\ Myron Yeager, Ph.D., Chair \\ Justine Van Meter, Ph.D. \\ Brian Glaser, Ph.D.
}

Wilkinson College of Arts, Humanities, and Social Sciences

Submitted in partial fulfillment of the requirements for the degree of 
The thesis of Alexa Paige Burnstine is approved.
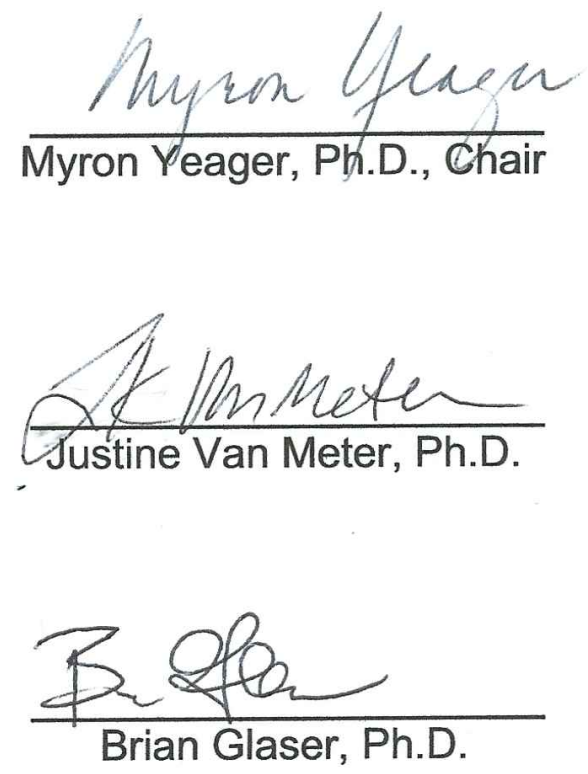

December 2019 
Terrence McNally's Universalizing Model: The Role of Disability in Andre's Mother; Lips Together, Teeth Apart; and Love! Valour!

Compassion!

Copyright (C) 2019

by Alexa Paige Burnstine 


\section{ACKNOWLEDGEMENTS}

I want to thank the Literature and Rhetoric Departments of Chapman University for my stellar, comprehensive English education. I also want to thank Dr. Justine Van Meter and Dr. Brian Glaser for their guidance and support of this work. Lastly, I want to thank my adviser, Dr. Myron Yeager, who first introduced me to Terrence McNally. This work would have been impossible to refine without his expertise and feedback on countless drafts. 


\begin{abstract}
Terrence McNally's Universalizing Model: The Role of Disability in Andre's Mother; Lips Together, Teeth Apart; and Love! Valour! Compassion! by Alexa Paige Burnstine

In his works such as Andre's Mother; Lips Together, Teeth Apart; and Love! Valour! Compassion!, playwright Terrence McNally utilizes categorically gay themes such as homophobia and living with HIV and AIDS in a time when little was understood about the illnesses. For these reasons, McNally critics customarily analyze McNally's plays with a queer theory lens. This work examines those same topics and others, but with a critical disability lens. Inspired by Robert McRuer's analytical partnership of queer, AIDS, and disabilities studies, this work assesses McNally's use of various types of languages and finds the figures who are characteristically presented as the contrast to normalcy are in fact normalized and hegemonized.
\end{abstract}




\section{TABLE OF CONTENTS}

$\underline{\text { Page }}$

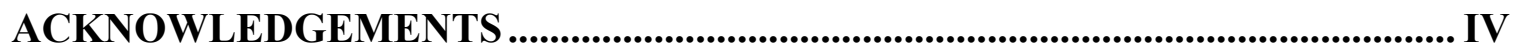

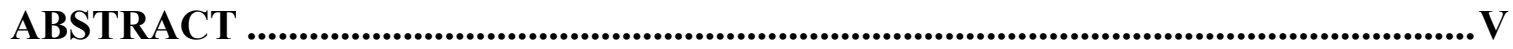

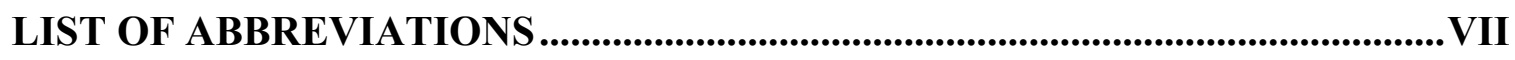

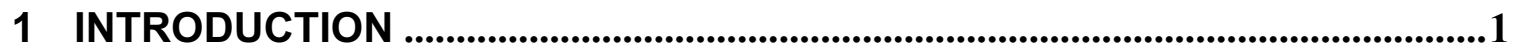

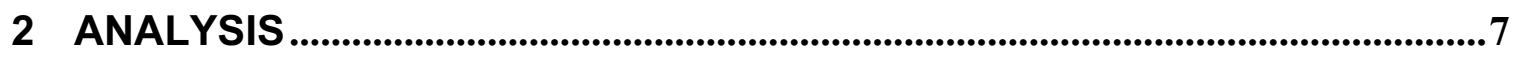

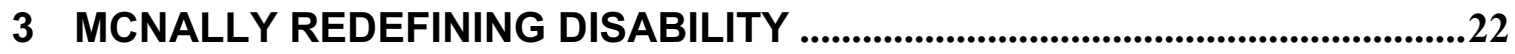

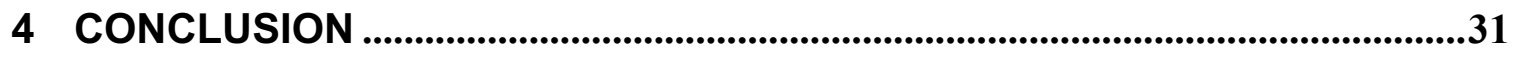

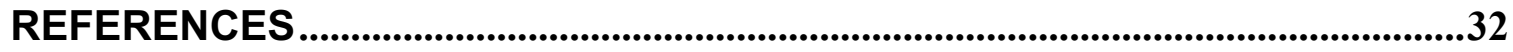




\section{LIST OF ABBREVIATIONS}

\section{Abbreviation Meaning}

ADA Americans with Disabilities Act

HIV Human Immunodeficiency Virus

AIDS Acquired Immunodeficiency Syndrome 


\section{Introduction}

On being asked about his thoughts on the labels "gay writer" and "gay play," Terrence McNally famously declared: "I'm a playwright. I think the era when we need to categorize people is over. I went from being 'the gay playwright Terrence McNally' to just being Terrence McNally...It was honorable to be a gay man and a gay writer. But I think categorizing people that way marginalizes them" (Galanes qtd. in The New York Times Style Magazine). While most of McNally's works explore gay themes (whether explicitly or more ambiguously), McNally appreciates that his plays can serve a broader understanding outside of the gay community by utilizing these motifs that he knows best. Typically, both queer and disabled identities are defined by binaries and regarded as deviations from the "norm" (i.e., the straight person and the non-disabled person). If, in a text, for example, there is a same-sex couple or a character in a wheelchair, the work is automatically categorized under a queer or disability genre despite the other thematic elements within the text. Often in this situation, the characters are rhetorically medicalized and treated as entities that need to be "cured." Ordinarily, this is a stigmatizing and destructive act, but in the plays Andre's Mother; Lips Together, Teeth Apart; and Love! Valour! Compassion!, McNally uses "othering" to normalize the usually marginalized groups. Terrence McNally successfully overcomes these minoritizing issues by embedding one identity within another but not allowing for either identity to solely define the character or his play and therefore destabilize the stereotypical relationships with the "norm." Although motifs and messages might be similar, the plays themselves are continually changing—different audiences, different actors, different 
stages—which is the beauty of a genre such as the play. The instability of the genre mimics McNally's upbringing with arguably disabled parents and his gay experience of which he tries to translate on the stage. These plays demand a shift of hegemonic power and lend a voice to those populations who may not yet have had outstanding representation in the theatre. This power shifts indicates the contrast of normalcy becoming normal.

One of the marginalized groups that is frequently "othered" are those living with disabilities. In McNally's plays, in particular, there are multiple characters with disabilities-in Lips Together, Teeth Apart, the disabilities are physical, in Andre's Mother, the disabilities are invisible, and in Love! Valour! Compassion!, it is a mix of both physical and invisible. ${ }^{1}$ Some of these disabled groups also belong to the gay community, but regardless of how they identify, these marginalized groups of people relate to each other in the ways they are treated by society. Unfortunately, the constructions of marginalized identities are not shaped by listening to or about the marginalized people but instead, are fabricated by the language of others who do not identify with that group. Also, both queer and disabled identities are often defined by binaries and regarded as deviations from the "norm," such as the straight person and the able-bodied person. Furthermore, in this situation, the characters are rhetorically

\footnotetext{
1 According to the Invisible Disabilities Association, "an invisible disability is a physical, mental or neurological condition that is not visible from the outside, yet can limit or challenge a person's movements, senses, or activities. Unfortunately, the very fact that these symptoms are invisible can lead to misunderstandings, false perceptions, and judgments."
} 
medicalized and treated as entities that need to be "cured" because "othering" determines that there is something missing or wrong with them and their differences. However, because McNally is able to rectify the act of "othering" by hegemonizing the marginalized groups in these plays, stigmas are dismantled, and the audience is able to separate socially constructed stereotypes from realistic portrayals and enjoy an unbiased viewing or reading experience. This instability of the play itself mirrors the societal instability of "othering" the marginalized people being portrayed on the stage.

The critical conjunction of queer and critical disability studies is relatively underrepresented. However, Robert McRuer of George Washington University has helped to explore the partnership of sexuality and able-bodiedness. In his text "Cripping the (Queer) Nation," McRuer explains how plays are a different viewing experience because audiences are literally seeing the sexual and bodily identities of the actors and their accessible (or likewise non-accessible) spaces. His primary focus is in destabilizing the rigidness of the "either you are, or you are not" dichotomy that separates abled from disabled and gay from straight. McRuer establishes that whenever a conversation enters disability discourse, a rhetorical separation arises through someone not being able to do something set against someone who is able to do that particular something. His work relies heavily on Bragdon v. Abbott et al., which establishes HIVIAIDS as a disability under the ADA. McRuer serves as one of the most visible scholars to explore both queer and disabled identities in conjunction.

Critics routinely look at queer identity and homophobia in McNally plays, but discussions that include disability are limited. There is limited research on McNally himself, let alone this specific lens applied to his works, which makes this work that 
uses a disability lens all the more valuable. While such critics as Toby Silverman Zinman, John M. Clum, and Peter Wolfe have offered serious scholarly exploration of McNally's works, Raymond-Jean Frontain's The Theater of Terrence McNally: Something About Grace offers the most comprehensive and systematic analysis of the McNally canon. Even still, there remains a lack of focus on disability. McRuer represents the few, if any, that combine the theoretical queer and disability lenses, but like most pioneers of a relatively unexplored field, McRuer's findings are not comprehensive. Inspired by Adrienne Rich's article about unavoidable heterosexuality and Judith Butler's conceptions of gender trouble, in his work "Compulsory AbleBodiedness and Queer/Disabled Existence," Robert McRuer merges queer studies and disability studies to propose notions of compulsory able-bodiedness and ability trouble. McRuer explains that "A critique of normalcy has similarly been central to the disability rights movement and to disability studies...Such scholarly and activist work positions us to locate the problems of able-bodied identity, to see the problem of the meaning of able-bodiedness as bound up with the problems it is being used to discuss" (McRuer 355). He is establishing that whenever a conversation enters disability discourse, a rhetorical dichotomy arises between someone not being able to do something and someone who is able to do that something. McRuer highlights the social rhetorics that simultaneously control and contain queer and disabled narratives and suggests new vocabulary as a solution. While McRuer's texts offer rich analysis, they often examine disability as a partner to sexuality and mainly focus on texts as cultural evidence for societal constructions rather than addressing the meanings in the texts themselves. In his groundbreaking Crip Theory: Cultural Signs of Queerness and Disability, McRuer 
also refers to the work of Eve Kosofsky Sedgwick, a notable critic in queer theory. He specifically focuses on Sedgwick's work with universalizing and minoritizing models in gender and sexuality.

Judith Butler and others routinely assert that sexuality is fluid, meaning it is not fixed, and the same argument can be made for disability in the way that there is an entire spectrum of categorizations of different types of disabilities (Butler 17). While someone may not identify as disabled now, there is always the possibility of future conditions, and while people may share a common disability, it is likely that each experience with that disability differs. The ADA defines disability as "a physical or mental impairment that substantially limits one or more major life activities, a person who has a history or record of such an impairment, or a person who is perceived by others as having such an impairment" ("Introduction to the ADA"). It also distinguishes HIV and AIDS as disabilities, and they are legally protectable against discrimination ("Fighting Discrimination"). Addiction is recognized by the ADA as well since it can "pose a substantial limitation on one or more major life activities" ("Questions and Answers"). In Jeff Kaufman's documentary on McNally, Every Act of Life, Terrence McNally recollects his parents as being "heavy drinkers" who would often choose drinking over cooking dinner for McNally and his younger brother, Peter. If we can consider being too drunk to provide children dinner as "a substantial limitation of a life activity" due to an alcohol addiction, then McNally's parents can be classified as being disabled and can point to them as McNally's introduction to disability, an introduction that may well have framed his interest for using disability tropes in his plays. This family 
history suggests McNally utilizes not only characters with physical impairments, but with mental and emotional impairments as well.

This work will trace the presence of disability in three McNally plays: Andre's Mother; Lips Together, Teeth Apart; and Love! Valour! Compassion!; by defining whether the disability is physical, emotional, mental, or spiritual. Starting with Andre's Mother, this work examines Andre's significance as a gay man who died from AIDS, and the role of his surviving partner, Cal, in the relationship with his mother. Next, there is an examination of Lips Together, Teeth Apart, where all of the characters are seemingly heteronormative and able-bodied, and how disability plays a role in that hegemonically framed narrative. The last play this study explores is Love! Valour! Compassion!, where all of the characters are gay and embody differing disabilities, with a final ballet scene that demonstrates McNally's exhibition of equality. Then, using disability and McNally critics, this work will develop McNally's use of disability themes in all three plays to show how McNally eliminates the "othering" of the disabled through language. Language, whether it be verbal, physical, or emotional, and even the lack thereof, acts as the ultimate equalizer for the marginalized characters even when confronted with the ultimate consequence of disability, death. 


\section{Analysis}

Andre's Mother is a McNally work that utilizes emotional disability over physical disability to frame a queer narrative. Andre, the titular character, has died from AIDS, but unlike other AIDS-centered plays, this story is not about him, but rather those he left behind. From the final monologue of Andre's lover, Cal, the audience learns that Andre's mother was unaware of both his sexuality and the fact that he had AIDS. Since Andre is not alive to speak for himself, Cal provides possible reasoning as to why Andre's mother was left in the dark: "But he was so afraid of hurting you and of your disapproval. We lose ourselves here. Our lives aren't furtive, just our feelings toward people like you are! A city of fugitives from our parent's scorn or heartbreak...The only thing that frightened him was you...I'm beginning to feel your disapproval and it's making me ill" (McNally 350-1). Andre's mother is not only nameless, but she is also speechless-she does not utter a single word for the entirety of this play. One interpretation of her silence is that she is horrified by the admissions about her son that are revealed through Cal's monologue. In other words, the shock of Andre's homosexuality and his death from a "homosexual disease" has rendered Andre's mother speechless. Another reading of Andre's mother's silence is that she is trapped by her biases and essentially disabled by her homophobia. Either way, his mother's silence allows the audience to understand and articulate Andre's terror that is the experience of having to tell his mother that he is not only gay but also sick. The "coming out" event and likewise the unacceptance of some friends and family that follows are occurrences that both gay and disabled characters alike frequently endure in 
texts. Often, texts with gay characters center around a "coming out" experience, which can be problematic considering having a "coming out" constructs "the closet" it is theoretically trying to destroy. The hegemonic norm, a heterosexual character, never publicly vocalizes its sexuality: "To be out is really to be in-inside the realm of the visible, the speakable, the culturally intelligible...To 'out' an insider, if it has any effect at all, can easily precipitate that figures fall from power and privilege" (Fuss 4).

Arguably, disabled characters experience their own "coming outs" of sorts too, especially when they have an invisible disability or illness such as AIDS. It is common in texts for a disabled character to have a declarative moment announcing their disability, much like a "coming out" moment for sexuality. Cal's final monologue serves as the vehicle for both of Andre's "coming outs": "But if you didn't know about Andre and me... If this hadn't happened, I wonder if he would have ever told you...Andre died of AIDS. I don't know how he got it" (McNally 350-1). Since Andre is also unable to speak for himself, it seems as though McNally is falling victim to two familiar disability tropes, villainous disability and helplessness, by letting Cal speak for Andre and his mother. On the one hand, Andre's mother's silence is perceived as villainous resentment towards her son's identities, and Andre's seemingly powerless silence conveys a message that homosexuality is fatal since he died from AIDS, a disease stereotypically associated with the gay community.

McRuer elaborates Andre's seemingly helpless silence when he says:

Demonized at worst, patronized, desexualized, or tolerated at best, people with HIVIAIDS have repeatedly been denied autonomous voices or subjectivities; the dominant meanings of the syndrome have rendered them passive objects or 
blank slates onto which the fantasies of those who would like to imagine themselves as "immune" from the epidemic could be written. (McRuer "Critical Investments" 221-2)

At first glance, it seems that McNally has stripped Andre of his "autonomous voice," but a closer reading suggests otherwise. McNally is implying something more significant about Andre's AIDS-related death that is not meant to be interpreted as homophobic or an act of silencing. Instead, it should be understood as a metaphorical representation for all of the lives that AIDS claimed by 1988 when this play debuted. McNally is not taking away voices, but instead providing them with a platform to be heard. Cal's speech not only gives a voice to AIDS patients and survivors but also to the queer community and even the heteronormative. Consequently, since Andre was already "out" with his sickness and his sexuality, McNally avoids exploiting a "coming out" event as a plot device. Similarly, McNally eliminates the "acquiring" of the Acquired Immunodeficiency Syndrome. Andre is remembered more for who he was as a person, not just for being gay or sick, because McNally eliminated the "coming out" and "acquiring" conversations.

McNally became intimately familiar with the AIDS epidemic and its effects when he lost two partners to AIDS-related illnesses, Robert Drivas in 1986, and Gary Bonasorte in 2001 (Frontain 79, 199). His play; Lips Together, Teeth Apart; was not the first play to put a spotlight on the AIDS epidemic (Andre's Mother predates Lips Together, Teeth Apart), but it stood out to critics and audiences alike because there are no on-stage homosexual characters. Once again, in a McNally play, gay characters are talked about but never speak for themselves. Six months following Lips Together, 
Teeth Apart's debut, Queen's Freddie Mercury would die from AIDS-related complications, and heterosexual NBA player Earvin "Magic" Johnson would announce that he was HIV-positive ("A Timeline"). A disease that was once privately reserved for the gay community had now become a public conversation for all people. These announcements brought AIDS issues into public focus and reflect what McNally does with disability in his plays: giving the marginalized community a voice.

In Lips Together, Teeth Apart, AIDS functions as a societal fear, like homophobia, for the main characters. Like Andre in Andre's Mother, McNally utilizes a silent gay man who has died from AIDS, Sally's brother, to frame suppressed homophobia and other queer disability contexts. For example, there is evidence with several pool scenes that Sally and the others are implicitly homophobic, even though Sally had no problem with inheriting her gay brother's beach house. In Act Three, all of the characters eventually gather by this pool, but none of them get into the water: "We all think it's infected. We all think it's polluted. We all think we'll get AIDS and die if we go in...One drop of water in your mouth or on an open sore and we'll be infected with my brother...I think we're very brave to dangle our feet like this. They may fall off" (McNally 249). The fear of contracting AIDS prevents the group from participating in an otherwise common summer activity, although they are entirely misinformed about how one actually contracts the Syndrome. Sally proceeds to splash John and Sam while taunting them with "You afraid of the water?" Sally eventually stops splashing the men and takes a drink of the pool water: "Then let's all get AIDS and die!" Sam responds to Sally by exclaiming, "I'm sorry your brother died but it's not my fault. I didn't kill him. I don't know about pools and AIDS and homosexuals. I don't want to. It frightens me, all 
right?" (McNally 249-50). Like Andre's Mother, a preliminary reading of this scene implies that McNally is suggesting that homosexuality equals death and Sally's brother has been rendered a "passive object" of "the fantasies of those who would like to imagine themselves as 'immune' from the epidemic" (McRuer "Critical Investments" 221-2). But a disability reading suggests that McNally is not silencing these issues but rather, starting conversations about them. Having the seemingly able-bodied heteronormative characters discuss their grossly misinformed fears of contracting AIDS sheds light on the common ignorances surrounding queer and disabled narratives.

Furthermore, AIDS and homophobia are not the only debilitating mechanisms at play in Lips Together, Teeth Apart. The play relies on the disabilities to show contrasts between the normative and the marginalized. For instance, John, Chloe's husband, has esophageal cancer: "I have cancer, Sally. It's only a little speck now, a microscopic dot of pain and terror but they tell me it will soon grow and ripen and flower in this fertile bed of malignancy that has somehow become my body. I never meant to" (McNally 194). Sam, Sally's husband and Chloe's brother, discovers John's secret after walking into his room unannounced. Chloe explains that John is fighting the cancer with pills, but they do not like to talk about it (257). Sam endures a splinter, mentions an upcoming surgery to repair a hernia, and grinds his teeth at night, which indicates an underlying physical and emotional disorder. John informs Sam that the splinter can cause an infection, creating an unnecessary urgency to remove the sliver, similar to the panic created about the swimming pool. Sally is pregnant and apprehensive after previously suffering multiple miscarriages. Her anxieties transcend her womb, though, as she becomes preoccupied with a swimmer. Sally observes the naked swimmer's routine of 
swimming out to sea alone and returning to shore, until one day, he disappears from view. Sally confirms the swimmer's identity when his battered body later washes up on shore, and she "grows increasingly unstable emotionally as the evening progresses" (Frontain 107). The swimmer, in his isolation, projects Sally's self-inflicted isolation and mental illness: "Insofar as the image of the solitary swimmer suggests the isolation of the individual as he struggles against challenging odds, it focuses the play's...dis-ease, raising the question why, if no one should be out that far alone, metaphorically so many people are" (Frontain 107). There is also evidence of an affair between Sally and John which suggests moral and "existential" disability as Frontain suggests:

CHLOE. It's over.

SAM. How do you know?

CHLOE. He told me.

SAM. And you believe him?

CHLOE. Yes. (McNally 237)

This brief conversation between Sam and Chloe serves as an "outing" for John and Sally's affair, similar to Cal's "outing" of Andre through monologue in Andre's Mother. Chloe arguably dabbles in prescription medications, but more importantly, she exhibits overtly insecure behaviors like changing outfits multiple times a day and randomly interjecting French words and phrases throughout her rambling dialogue, because she is emotionally disabled. There is even an incestual suggestion when Chloe asks to see her brother's penis. Chloe suffers from a "sense of cultural inferiority" (Frontain 117). Another symptom of her emotional disability is her overt homophobic language: "It's entirely the parents' fault. If any of our three [children] turned out that way, I would feel 
like killing myself' (McNally 230). She elaborates on this sentiment when she says: "Lesbians make me a little nervous but l've never had a problem with men" (McNally 220). Yet, these statements contradict her neighborly actions: "Thank you...You enjoy yours. Nice talking to you...What's your name?" (McNally 218). Ironically, Chloe uses French, one of the five romance languages, when her derogatory comments are anything but romantic. These homophobic contradictions and erratic behaviors demonstrate a symptom of her debilitating mental state. Fittingly, Chloe's husband John exhibits similar emotional disability through prejudiced speech as well: "It says here that eleven percent of this country is black. That's amazing. I would have thought it was more like fifty...Doesn't this country seem more than eleven percent black to you?" (McNally 181-2). John also utilizes racial, sexist, and homophobic slurs throughout the play. Frontain notes that "The 'malevolence' that grows inside John is not simply his cancer, it is an impatience with racial, gender, and sexual identity difference that derives from his feeling negated or diminished by others" (110).

All four characters endure different types of disabilities, but they share a common incapacitating phobia as evident by their language: Sally worries about raising her unborn child to be gay, Sam expresses uneasiness with "locker room stuff" and homosexuality, Chloe admits to being nervous around lesbians, and John utters all sorts of slurs (McNally 235). Conversely, even though Sally, Sam, John, and Chloe treat the homosexual as the diseased "other," McNally uses the heteronormative group's ailments and fears to show that heterosexuals are diseased too, and in ways they might not even realize, as with Chloe's insecurities. Usually an identity such as homosexual 
or disabled would minimize a character's importance, but through the disabled couples' misinformed dialogues all people are equalized.

Douglas Baynton argues that disability is "a constitutive element of social relationships" and that "the concept of disability has functioned rhetorically to structure thought about social hierarchies in general" (562). As evident by the swimming pool conversation, Sally, Sam, John, and Chloe use AIDS and its side effects as a means for belittling the gay population. Baynton elaborates by expressing that "the exclusion of disabled people has long been one of the fundamental imperatives of American immigration policy" (564). By spending their Fourth of July weekend on Fire Island, the two couples have essentially immigrated to the epitome of gay America and partake in multiple acts of exclusion against the island's own residents. Neighbors graciously share American flags with the couples during a Fourth of July celebration, but even this charitable act of national loyalty and social unity is met with hostility:

JOHN. (A packet of small American flags held together with a rubber band is tossed onto the deck...) Thank you. (Red, white and blue streamers and confetti are being tossed down onto the deck from the taller houses on each side). SAM. (Calling off.) Thank you. Thank you. (To others on the deck) They gonna come over here tomorrow and clean this mess up? (McNally 255)

This behavior is ironic considering the couples are guests of the island and are imposing themselves onto Fire Island's gay culture. The "diseased" community that has been "othered" is celebrating their country's birthday despite repeatedly encountering societal discrimination like those acts demonstrated by the couples, and yet the "normal" Americans reluctantly participate in the celebration of patriotism. That is, after 
all, how Chloe describes themselves: "I know l'm not supposed to say 'normal.'

'Straight' is the word I'm supposed to use. I hate it. It sounds like a ruler. And heterosexual is just plain ugh-y" (McNally 230). This "hate" language is further evidence of Chloe's homophobia. There are plenty of instances in this play of dichotomies between two cultures surfacing, which is why the role of the disabilities is so important. The disabilities reconcile the discrimination because it creates an unbiased equivalence amongst all people in the text, both gay and straight:

SALLY. I don't think I have anything against gay men, I just don't want to be the only nongay people here.

CHLOE. You don't want to be a token anything. I hear you. Who wants to feel like everyone's staring at them? (McNally 220)

John, Sam, Chloe, and Sally try to separate themselves from the neighbors through their hate language, but on Fire Island, the gay residents are the hegemonic and ablebodied figures.

Similar to Andre's Mother and Lips Together, Teeth Apart, the HIVIAIDS positive characters in Love! Valour! Compassion! already have the disability, and there is no contracting-of-an-illness narrative. McNally eliminates the "acquiring" storyline of the acquired immunodeficiency syndrome, as he eliminates the "coming out" storyline for Andre, for both Buzz and James, thus presenting characters with different traits rather than identity-centered disabilities. Ceballos Muñoz echoes this sentiment when he suggests that "AIDS is assigned its place from the beginning of the play in a sort of silenced presence, and even only shared by the characters who undergo its effects. But their conversations articulate a positive discourse of the disease instead of a self- 
loathing or self-lamenting one" (Ceballos Muñoz 46-7). McNally is reinventing the typical disability and queer storylines by approaching them positively and optimistically.

In her pioneering gender study, Epistemology of the Closet, Eve Kosofsky Sedgwick claims that "in the concurrent public-health constructions related to AIDS, for instance, it is far from clear that a minoritizing discourse of persons ('risk groups') is not even more oppressive than the competing, universalizing discourse of act ('safer sex')" (Sedgwick 58). In Love! Valour! Compassion!, McNally is "show[ing] what else gay men were doing besides having AIDS and dying" (Galanes qtd. in The New York Times Style Magazine). Buzz and James both have successful careers, hobbies, and manage to fall in love despite their sicknesses or sexual orientations. The disability of AIDS acts as a catapult for Buzz and James' relationship:

BUZZ. How sick are you?

JAMES. I think I'm in pretty good nick, but my reports read like something out of Nostradamus. (He looks at Buzz.) I should have died six months ago.

BUZZ. Try eighteen. Do you have any lesions?

JAMES. Only one, and l've had it for nearly a year.

BUZZ. Where is it? . . May I see it?

JAMES. It's—All right...It doesn't disgust you?

BUZZ. It's going to be me. (McNally 418)

Muñoz suggests that “James and Buzz's love makes us displace our view from the horror of HIV effects towards a loving couple, thus provoking the audience to be moved and touched and to accept them as just tender human beings. We do not witness a 
rotten body, but a body reconstructed by means of empathy, affection and love" (47). Buzz and James are the representative figures of a broader disability discourse.

It is through the AIDS storyline that McNally redefines what it means, in particular, to be a disabled, gay man. After the exchange between Buzz and James, Buzz kisses James' lesion, bringing love and compassion to the disease often surrounded by disgust and isolation. Muñoz further illuminates the significance of this moment: "the audience is forced to focus its sight on the lesions and to indulgently contemplate the marks of the disease on James's body. But James's attitude is what softens the looks of the lesions and makes the spectator feel compassion instead of disgust...McNally's point is to show that gay people suffer as everybody else does and that we all will die anyway" (48). Just as Bobby expresses: "People think blindness is the most awful thing that can happen to a person. Hey, I've got news for everybody: It's not"; others would argue that a fatal debilitating disease like AIDS would be "the most awful thing that can happen to a person," but McNally is arguing that no disability or sexual identification should be prioritized or pitied over the other (372).

Bobby's exclamation about how being blind is not "the most awful" disability a person can have highlights the frequently exercised helpless victim trope. Arthur says: "I read an article that said most blind people hated to be helped." Bobby replies: "We love to be helped. We hate to be patronized. It's people assuming we want help that pisses us off. l'm standing at the corner waiting for the light to change and some jerk grabs my elbow and says, 'Don't' worry, I've got you,' It happens all the time"' (McNally 372). McNally is describing the semiotic filtering that happens all too often with people with disabilities. People tend to create visual associations with disabilities (like seeing a 
blind man at a corner and assuming he needs help crossing the street), and the meanings we create occur between these semiotically filtered instances. Two examples of these semiotic filters are what Eve Kosofsky Sedgwick describes as the minoritizing model and the universalizing model. In terms of sexuality, a minoritizing view sees sexuality as of "active importance primarily for a small, distinct, relatively fixed...minority," and the universalizing model views sexuality as a matter of "continuing, determinative importance in the lives of people across the spectrum" (1). For instance, sexuality has been perceived and studied based on the heterosexual, and anything nonheterosexual is an "other"- -the minoritizing model—and all people fall somewhere on the sexuality spectrum and can technically be regarded as the same--the universalizing model. In the previous conversation, Bobby is both "othered" by Arthur when he assumes, he needs help attending to his wound and universalized when Arthur subjects Bobby to a grouping of blind people he read about somewhere. But when McNally allows Bobby, a gay disabled character, to voice his frustrations with the helpless victim trope, there is a reclaiming of narrative power for the disabled population.

Language has become the ultimate equalizer for the marginalized characters. Since Bobby's lack of sight does not allow Bobby to rely on appearances, he has to rely on language. When Perry asks Bobby if he ever wonders what his partner, Gregory, looks like, Bobby assuredly replies: "I know what he looks like" and proceeds to describe Gregory and his blonde hair (McNally 385-6). Perry protests that Bobby could not possibly know what blonde hair looks like since he has never seen it. Bobby explains that it is in his "mind's eye" that he "see[s]... the same things" that Perry sees (386). When Bobby arrives at Gregory's house, he immediately thanks God for "the 
trees, the lake, [and] the sweet, sweet air" despite not knowing what the trees and lake look like (394). Language allows for Bobby to construct sights in his mind and see what Perry and other non-visibly impaired people see, thus eliminating the hinderances of his disability.

Gregory, an aging choreographer, has a stutter that is signified by a series of "ums": “Um. I'm sorry. Um. I don't do this. Um. On purpose. Um" (McNally 369). Gregory's stutter threatens to isolate him because of his inability to use words like the other men, but Gregory adapts by employing other means of communicating. Appropriately, dance plays a significant role in Love! Valour! Compassion!, especially with Gregory. In his article "Terrence McNally and the Dance of Death," Frontain describes the final Swan Lake dance scene in particular and its rhetorical function in the play: "For the moment of the dance, however, the threat of the immolation is met by the men who join hands in solidarity and support each other with love, valor, compassion" (48). Moreover, there is another purpose for the dance scenes. Towards the end of the play, Gregory leaves the group to work on choreography in his home studio. Perry acknowledges that this work session is different for Gregory; however, because this time Gregory has left the studio curtains open despite "always ke[eping] the studio curtains closed." Perry further suggests that "it was as if [Gregory] wanted us to watch him," which Gregory confirms later when he says: "I wanted [Ramon] to watch" (McNally 454-6). Spoken language fails Gregory because of his stutter, but he turns to body language for reconciliation. The language of dance for Gregory acts in a similar way that spoken language helped Bobby. By watching Gregory dance through the windows, Ramon finally admits how "fucking good" of a dancer Gregory is and how he would be 
honored to work with such a seasoned choreographer despite earlier expressing jealousy towards Gregory. Since Ramon admits that he loves himself the most when he dances and "the rest of the time [he] just feel[s] okay," it is only through watching Gregory dance that he understands his older host in a way that he was unable to connect with before (405). In this case, Gregory and Ramon communicate through the same language despite their differences in age, culture, and professional accomplishment. Dance allows Gregory not only to communicate but also to be "heard" in a way that everybody can comprehend, regardless of his speech impairment.

Again, in examining the scene when Buzz kisses James' Kaposi's sarcoma lesion (KS lesion), it is the act of kissing that relays the message, not actual words. In his work "Communal Survival and the Dance of Death," Frontain suggests that McNally utilizes empathy as "the most fundamental function of the moral imagination" (187). Similar to Gregory's dancing and Bobby's mental processing, this wordless performance, too, acts as an equalizer for James and his AIDS. The kiss signifies Buzz's acceptance of James as an equal able body despite James' disability and shows that he does not think lesser of James even with his "diseased" appearance. Furthermore, Love! Valour! Compassion! is the only one of these three plays where a character with AIDS has an active role in the story and speaks lines. The lack of verbal language for these characters in the other two plays, however, communicates just as much as James, the McNally character living with AIDS. The empathetic acts of sharing the flags with the heterosexual/disabled neighbors and leaving the house to Sally and her homophobic friends in Lips Together, Teeth Apart serve the same equalizing 
purpose as Buzz kissing James' lesion. The actions of the givers display neither ill-will nor judgment towards the receivers despite their inequality in abilities. 


\section{McNally Redefining Disability}

Language has become the ultimate equalizer for the marginalized characters. Since Bobby's lack of sight does not allow Bobby to rely on appearances, he has to rely on language. When Perry asks Bobby if he ever wonders what his partner, Gregory, looks like, Bobby assuredly replies: "I know what he looks like" and proceeds to describe Gregory and his blonde hair (McNally 385-6). Perry protests that Bobby could not possibly know what blonde hair looks like since he has never seen it. Bobby explains that it is in his "mind's eye" that he "see[s]... the same things" that Perry sees (386). When Bobby arrives at Gregory's house, he immediately thanks God for "the trees, the lake, [and] the sweet, sweet air" despite not knowing what the trees and lake look like (394). Language allows for Bobby to construct sights in his mind and see what Perry and other non-visibly impaired people see, thus eliminating the hinderances of his disability.

Gregory, an aging choreographer, has a stutter that is signified by a series of "ums": “Um. I'm sorry. Um. I don't do this. Um. On purpose. Um" (McNally 369). Gregory's stutter threatens to isolate him because of his inability to use words like the other men, but Gregory adapts by employing other means of communicating. Appropriately, dance plays a significant role in Love! Valour! Compassion!, especially with Gregory. In his article "Terrence McNally and the Dance of Death," Frontain describes the final Swan Lake dance scene in particular and its rhetorical function in the play: "For the moment of the dance, however, the threat of the immolation is met by the men who join hands in solidarity and support each other with love, valor, compassion" 
(48). Moreover, there is another purpose for the dance scenes. Towards the end of the play, Gregory leaves the group to work on choreography in his home studio. Perry acknowledges that this work session is different for Gregory; however, because this time Gregory has left the studio curtains open despite "always ke[eping] the studio curtains closed." Perry further suggests that "it was as if [Gregory] wanted us to watch him," which Gregory confirms later when he says: "I wanted [Ramon] to watch" (McNally 454-6). Spoken language fails Gregory because of his stutter, but he turns to body language for reconciliation. The language of dance for Gregory acts in a similar way that spoken language helped Bobby. By watching Gregory dance through the windows, Ramon finally admits how "fucking good" of a dancer Gregory is and how he would be honored to work with such a seasoned choreographer despite earlier expressing jealousy towards Gregory. Since Ramon admits that he loves himself the most when he dances and "the rest of the time [he] just feel[s] okay," it is only through watching Gregory dance that he understands his older host in a way that he was unable to connect with before (405). In this case, Gregory and Ramon communicate through the same language despite their differences in age, culture, and professional accomplishment. Dance allows Gregory not only to communicate but also to be "heard" in a way that everybody can comprehend, regardless of his speech impairment.

Again, in examining the scene when Buzz kisses James' Kaposi's sarcoma lesion (KS lesion), it is the act of kissing that relays the message, not actual words. In his work "Communal Survival and the Dance of Death," Frontain suggests that McNally utilizes empathy as "the most fundamental function of the moral imagination" (187). Similar to Gregory's dancing and Bobby's mental processing, this wordless 
performance, too, acts as an equalizer for James and his AIDS. The kiss signifies Buzz's acceptance of James as an equal able body despite James' disability and shows that he does not think lesser of James even with his "diseased" appearance. Furthermore, Love! Valour! Compassion! is the only one of these three plays where a character with AIDS has an active role in the story and speaks lines. The lack of verbal language for these characters in the other two plays, however, communicates just as much as James, the McNally character living with AIDS. The empathetic acts of sharing the flags with the heterosexual/disabled neighbors and leaving the house to Sally and her homophobic friends in Lips Together, Teeth Apart serve the same equalizing purpose as Buzz kissing James' lesion. The actions of the givers display neither ill-will nor judgment towards the receivers despite their inequality in abilities.

A closer thematic examination of the particular use of language and how he treats death in each of the three plays will reveal how McNally successful hegemonizes the marginalized. The unnecessary urgency surrounding Sam's foot splinter in Lips Together, Teeth Apart is created through language: “I can't look! It's big! It's huge. It's in there about six inches ... Is there a hospital on the island? ... (John holds up a sliver that is almost two inches long)" (McNally 238-9). Sam's expressive language makes the splinter seem like a worse injury than what it really is. When John talks about his cancer, or more specifically does not talk about his cancer since it is Chloe who reveals this diagnosis to the majority of the group, it is a stark contrast to Sam's splinter language despite the cancer being the more severe impairment of the two. When John privately discloses his cancer to Sally, who is unaware that he is even speaking to her, he describes it as a "microscopic dot of pain and terror." He continues, 
"No cancer will be worse than mine ... None more virulent, more horrendous, more agonizing" (McNally 194-5). Frontain elaborates on this moment in "The Loneliness of the Long-Distance Swimmer" when he says: "even as he imagines verbalizing his acute anxiety to her, she is herself preoccupied ... [John is] in danger of drowning emotionally" (109). There is a disconnect between John's audience-less speech to Sally and his refusal to talk about his cancer at all with others, which further emphasizes his emotional disability. This emotional disability of John's reflects Sam's confusing and over-exaggerated sentiment towards his splinter. It is through the language and simultaneous lack of language that allows for an equalizing of the two conditions. Likewise, in Andre's Mother, Andre's mother's lack of language mirrors her son's inability to speak. Again, McNally uses language, or the lack thereof, as his own universalizing model—both the seemingly able-bodied mother and the son who died from AIDS are parallel in their inability to speak, thus rendering them equal.

The fear of death is disabled through language and the community it creates.

Death is often portrayed as a consequence of disability which is especially problematic because it conveys the message that living a life with a disability is not worth living at all. José Alaniz contributes to this conversation in Death, Disability, and the Superhero: The Silver Age and Beyond when he says: "The question of how to dispose of one's own life lies at the intersection of autonomy, free will, and societal preconceptions about 'worthwhile' lives. In the case of the disabled, who live in ableist societies with eugenicist histories and a climate of medical paternalism, such a question hits especially close to home" (Alaniz 98). Even McNally's AIDS themes focus on life: "No longer understood as an automatic death sentence, HIV was reconfigured in the cultural 
imagination as a new way of life" (Barounis 136). Instead of utilizing death as a consequence of disability, McNally works towards showing characters living lives with disabilities, and death is a simple inevitability.

In Andre's Mother, Andre has already died from AIDS, and his partner, Cal, has tested negative for the fatal condition. Cal's mother is also dead, but he, his sister, and his father have all been able to continue with their lives. For Cal, death has become an integral part of his family life, but it is the death of Andre that has united Cal's family with Andre's family. Despite it being a somber gathering for a death, it is through this assembly and Cal's eulogistic speech that Andre's true self is finally revealed to his mother. The seemingly hegemonic Fourth of July vacationers in Lips Together, Teeth Apart will not even submerge themselves in the pool for fear of contracting AIDS and consequently dying. It is Sally, though, who eventually not only makes contact with the pool water, but also takes a drink from it. This action, along with her ability to look at the presumedly gay, drowned swimmer's corpse proves Sally is not as afraid of death as the others. Despite her underlying homophobic sentiments, it is clear that Sally feels compassion for the dead swimmer. When Sally proceeds to splash her companions with the erroneously-assumed infected pool water while exclaiming, "Everybody's afraid of dying around here" as they react in horror (McNally 249), she further solidifies her indifference to death while everybody else is frightened. The pool becomes a means of connecting Sally not only with the other guests as she splashes them, but also with her dead brother, whose gay and diseased lifestyle she could not accept when he was alive: "I should have stood up for [my brother] because ... He couldn't stand up for himself. I just looked away" (McNally 198). The pool acts as a community where not 
only are her paranoia and isolation disabilities partially reconciled, but also her guilt about her brother because she aligns herself with the dead swimmer who died in water and her dead brother who owned the pool. Her heterosexual and physically ablebodied lifestyle will not exempt her from suffering a similar fate.

When Buzz kisses James' KS lesion in Love! Valour! Compassion!, there is no fear of death. When James asks Buzz why his lesion does not disgust him, Buzz responds simply, "It's going to be me" (McNally 418). The kiss, a wordless action of love, signifies Buzz's acceptance of his HIV diagnosis and the consequences that might accompany it, and defines community. The kiss is more than just a romantic act, it is a uniting act, a means of connection. In Act II, McNally kills another speechless character. Bobby's leisurely summer day is disrupted when he receives a phone call informing him of his sister's untimely death: "It was a freak accident ... Something to do with a faulty installed ride at a fun fair" (McNally 421). Bobby is then "heard howling his grief' which breaks the silence of the friends whom are unsure of what to do (421). Frontain puts forth that the howl "dramatically brings to the center of the eight friends' existence the threat of oblivion that otherwise hovers at its edges ... The immediate human impulse. . .is to avert our gaze when we feel helpless to relieve someone else's distress or suffering" ("Something about Grace" 182). The guests decide to stay at the lake house with their grieving friend instead of leaving him with his sorrows. McNally gives little detail about Bobby's "wordless" sister, but it does not matter. To speak about her and her death brings the men together despite their differing disabilities, simply as human beings. 
At the end of Love! Valour! Compassion!, the men perform Tchaikovsky's Swan Lake for an AIDS benefit. But there is a queering of Tchaikovsky's dance when Gregory choreographs the classic ballet number to feature only gay, disabled men who dance linked, hand in hand. ${ }^{2}$ Also, the men are dressed in tutus and pointe shoes, which are garments reserved for female ballerinas. The physical toll of AIDS becomes apparent when James collapses during rehearsal, but he assures his worried friends that he is "fine," and they should "go on" without him (462). Even Bobby participates in the dance and exclaims, "I'm not handicapped. Not anymore. I'm visually challenged" (McNally 460) while not allowing for his blindness to disqualify him from performing with his friends. Then, one by one, each member of the ensemble steps out and informs the audience of their future deaths. Frontain suggests that "while the men cannot save each other from the inevitability of death, they can restore each other from the paralyzing fear of dying ... [and] the encroaching darkness is transformed by the communal warmth" (196). When they unite through the wordless language of dance, the men are able to confront death, to speak about it, together. The threat of death is eliminated, because as it is in Andre's Mother, Lips Together, Teeth Apart; and Love! Valour! Compassion! too, death does not discriminate against the gay or the disabled. The men have bonded together by creating a community and the inevitably of death contributes to the bond of humanity of the disabled and the hegemonic.

McNally scholars often discuss his use of AIDS and homosexual tropes, but there is a lack of focus on his use of disability despite the numerous characters that present identities with disabilities. Andre, in Andre's Mother, died from AIDS before

\footnotetext{
${ }^{2}$ Tchaikovsky is routinely accepted as having been gay and suffered from depression ("Tchaikovsky: A Life").
} 
being able to tell his disapproving, homophobic mother that he was sick. Sally, Sam, John, and Chloe in Lips Together, Teeth Apart all suffer from various physical disabilities from cancer to a hernia, but their collective emotional and spiritual disabilities such as homophobia, insecurity, and paranoia supersede their physical disabilities. In Love! Valour! Compassion!, Bobby is blind, Gregory stutters, James has AIDS and Buzz is HIV positive. While some of the characters appear to represent the hegemonic, disability affects them all, whether it is physical or invisible. McNally normalizes disability in his texts, because as the disabled, they are normative.

In Mothers and Sons, a sequel of sorts to Andre's Mother, Andre's mother declares: "Words are the bridge we build across the void that separates us" (McNally 655). What is asserted in Mothers and Sons might also be applied to Andre's Mother; Lips Together, Teeth Apart; Love! Valour! Compassion! and how McNally uses language, or the lack thereof, to elevate the typically stifled supporting role of disability—language is McNally's universalizing model. He understands that language creates experience and community, but without it, there is isolation. Andre's death represented more than just another loss from AIDS because of Cal's speech to Andre's silent mother. John's prejudiced language distances him from his wife, his lover, and his friend, but Sally's final statement of acceptance of the pool that once frightened her symbolizes recognition of her gay brother who also died from AIDS and reconciliation of her debilitating paranoia. Gregory's stutter physically kept him from connecting with his friend, but his body language and use of dance provided a means for him to communicate. Buzz shows James through a love language, a kiss, that he is not afraid of, nor will he think less of James and his AIDS. Bobby is blind but declares he is not 
handicapped, and it will not stop him from participating in the ballet. The Swan Lake reprisal at the end of Love! Valour! Compassion!, or the Dance of Death as Frontain calls it, is the ultimate display of McNally's universalizing model. ${ }^{3}$ The disabled men in tutus who step forward to speak about their future deaths completely destabilizes both the heteronormative and the hegemonic able-bodied in a single scene. The men are not afraid of death either, despite living with ailments that could contribute to an early one. Like his use of language, McNally uses the trope of death to be used as an equalizer, a means of uniting, rather than a consequence disability. All types of characters experience death in McNally plays, and likewise, all types of characters die in McNally plays, including the hegemonic and the othered. Disability does not mean unequal, and McNally realizes that language as a means of redefining tropes such as death is the means of rectifying this.

\footnotetext{
${ }^{3}$ The Dance of Death is drawn from the trope of the dance macabre, routine in dance and opera (Snelson "Bad for Your Health").
} 


\section{Conclusion}

There is a lack of concentration with a critical disability studies lens in McNally studies, because theorists predominantly focus on queer theory. The goal of this work is to critically contribute to both the McNally canon by applying a disability studies lens, and to disability studies by utilizing plays. The intersectionality of lenses and genres provides for a unique academic look at a characteristically non-academic source. Specifically, the genre of the play allows for an exclusive look at the conjunction of criticisms because of its inclusive, interactive environment between actors and audiences. Not only does the theatre audience act as a community for the customarily isolated and marginalized groups, but the theatre encourages the audience to see a perspective different from their own such as the experience of a gay man disabled by AIDS. Furthermore, the plays themselves promote social dialogue. By applying a critical disability lens and McNally's universalizing model of language, the gay man disabled by AIDS is no longer the "other," but the hegemonic. This application of a critical disability lens demonstrates how McNally's specific treatment of disability tropes though language, including conversations about death, do not marginalize but instead elevate and equalize the disabled. Asserting that McNally is no longer a "gay playwright," he is not a disability playwright either but ultimately a playwright. 


\section{References}

"A Timeline of HIV and AIDS." The U.S. Department of Health \& Human Services, https://www.hiv.gov/hiv-basics/overview/history/hiv-and-aids-timeline Alaniz, José. Death, Disability, and the Superhero: The Silver Age and Beyond. University Press of Mississippi, 2014.

Baranouis, Cynthia. Vulnerable Constitutions: Queerness, Disability, and the Remaking of American Manhood. Temple University Press, 2019.

Baynton, Douglas. "Slaves, Immigrants, and Suffragists: The Uses of Disability in Citizenship Debates.” PMLA, vol. 120, no. 2, 2005, pp. 562-567.

Butler, Judith. "Identity, Sex, and the Metaphysics of Substance." Gender Trouble: Feminism and the Subversion of Identity, Routledge, 1990, pp. 16-24.

Ceballos Muñoz, Alfonso. “Gay Men Only, Please! The ‘Performance' of Gay Identity in Terrence McNally’s Love! Valour! Compassion!" Revista de Estudios Norteamericanos, vol. 12, 2007, pp. 37-54.

Clum, John M. Terrence McNally and Fifty Years of American Gay Drama. Cambria Press, 2016.

Frontain, Raymond-Jean. The Theater of Terrence McNally: Something About Grace. Fairleigh Dickinson University Press, 2019.

---. "Terrence McNally and the Dance of Death." CEA Critic: An Official Journal of the College English Association, vol. 71, no. 2, 2009, pp. 25-56.

Fuss, Diana. Inside/out: Lesbian Theories, Gay Theories. Routledge. 1991. 
Galanes, Philip. "A Conversation with Terrence McNally, the Bard of American Theater." The New York Times Style Magazine, 10 April 2019, https://www.nytimes.com/interactive/2019/04/10/t-magazine/terrence-mcnallyinterview.html.

"Information and Technical Assistance on the Americans with Disabilities Act." United States Department of Justice Civil Rights Division, https://www.ada.gov/hiv/index.htm.

Mallow, Anna. "Is Sex Disability? Queer Theory and the Disability Drive." Sex and Disability, edited by Robert McRuer, Duke University Press, 2012, pp. 285-312.

McNally, Terrence. "Andre's Mother." Terrence McNally: 15 Short Plays, Smith and Kraus, Inc., 1994, pp. 347-351.

---. "Lips Together, Teeth Apart." Terrence McNally: Selected Works, A Memoir in Plays, New York, Grove, 2014.

---. “Love! Valour! Compassion!" Terrence McNally: Selected Works, A Memoir in Plays, New York, Grove, 2014.

---. "Mothers and Sons." Terrence McNally: Selected Works, A Memoir in Plays, New York, Grove, 2014.

McRuer, Robert, and Abby Lynn Wilkerson. "Cripping the (Queer) Nation." GLQ: A Journal of Lesbian \& Gay Studies, vol. 9, no. 1-2, Jan. 2003, pp. 1-23.

McRuer, Robert. Crip Theory: Cultural Signs of Queerness and Disability. New York University Press, 2006.

---. "Critical Investments: AIDS, Christopher Reeve, and Queer/Disability Studies." Journal of Medical Humanities, Vol. 23, Nos. 3-4, 2002, pp. 221-237. 
Mitchell, David T. and Sharon L. Snyder. Narrative Prosthesis: Disability and the Dependencies of Discourse. University of Michigan Press, 2001.

Sanchez de Carmona, M. "Creativity, Artistic Genius and Bipolar Disorder." Bipolar Disorders, vol. 17, June 2015, pp. 15-16.

Sedgwick, Eve Kosofsky. Epistemology of the Closet. University of California Press, 1990.

Snelson, John. "The Dance of Death: In Art, Ballet Can Be Very Bad for Your Health." Royal Opera House, 10 January 2014, https://www.roh.org.uk/news/the-danceof-death-in-art-ballet-can-be-very-bad-for-your-health.

“Tchaikovsky: A Life.” Tchaikovsky Research, http://en.tchaikovskyresearch.net/pages/Tchaikovsky:_A_Life.

"Terrence McNally: Every Act of Life." American Masters, Directed by Jeff Kaufman, PBS, 2019.

Wolfe, Peter. The Theater of Terrence McNally: A Critical Study. McFarland, 2013.

Zinman, Toby Silverman. Terrence McNally: A Casebook. Garland Publishing, Inc., 1997. 
